
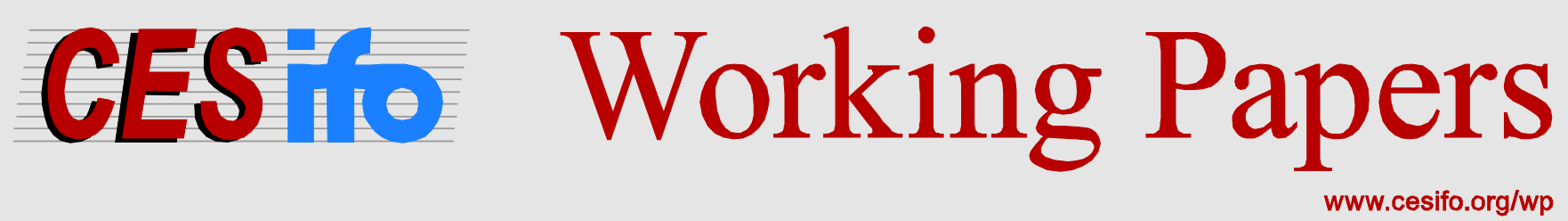

\title{
Decomposing China's Export Growth into Extensive Margin, Export Quality and Quantity Effects
}

\author{
Yue Gao \\ John Whalley \\ Yonglei Ren
}

CESIFO WORKING PAPER NO. 4251

CATEgory 8: TRAde Policy

MAY 2013

An electronic version of the paper may be downloaded

- from the SSRN website:

- from the RePEc website:

- from the CESifo website:

wWw.SSRN.com

www.RePEc.org

www.CESifo-group.org/wp

\section{CESifo}




\title{
Decomposing China’s Export Growth into Extensive Margin, Export Quality and Quantity Effects
}

\begin{abstract}
This paper decomposes the growth of China's export into three parts: growth in the extensive margin, increased quantity and increased prices; we perform a series of empirical analyses using China's export data at HS-6 digit to analyze the characteristics of China's export growth. From 1995 to 2010, China's export growth was mainly driven by quantity growth with a contribution of 66.81\%; but if we divide the time period from 1995 to 2010 into five even phases, we find the three parts of export growth show different trends. The contributions of the extensive margin and price changes are decreasing, but quantity shows an increasing trend. China's export is better than the rest of the world after the financial crisis and in 20082010, with a strategy of lowering price and promoting sales in 2009 when facing a slump in export markets; resuming price increases and increasing sales moderately in reaction to improving export conditions in 2010.
\end{abstract}

JEL-Code: F140.

Keywords: product fragmentation, heterogeneity, export, FDI.

\author{
Yue Gao \\ School of Business \\ Shandong University of Technology \\ No.88 Gongqingtuan Road \\ Zibo, Shandong province, China, 255012 \\ gaoyue01@163.com
}

\author{
John Whalley \\ Department of Economics \\ Social Science Centre \\ University of Western Ontario \\ London, Ontario N6A 5C2, Canada \\ jwhalley@uwo.ca
}

\author{
Yonglei Ren \\ School of Business \\ Shandong University of Technology \\ No.88 Gongqingtuan Road \\ Zibo, Shandong province, China, 255012 \\ yonglei1019@126.com
}

April 2013

We are grateful for the financial support from the Ontario Research Fund (ORF). 


\section{Introduction}

Recent research in international trade has focused on the trade growth. Many authors divide the export growth into two parts. One is called the extensive margin which generally means a nation exports commodities that has not exported before or ceases to export goods that it has exported before. The extensive margin is often defined as the growth of exports due to change in varieties. The other form of export growth is on the intensive margin which usually means exporting goods that have been previously exported. The intensive margin generally describes to what extent trade increases or decreases due to the existing traded commodities. There are some extensions of the definition of extensive margin and intensive margin, for example, some define intensive and extensive margin at the country-product level, taking both new products exported and new trade partners as extensive margin; and some look at new exporting firms as the extensive margin.

The structure of the paper is as follows: Firstly, as theoretical background, we relate international trade theory and economic growth theory with the decomposition of export growth; Secondly, we present the calculation method for the three parts of export growth; and then perform a series of empirical analyses using China's export data at HS-6 digit; Finally, we offer a conclusion.

The main contributions of this paper are as follows: Firstly, it is the first paper to study changes in the three parts of export growth. It divides the overall time period in question into several even phases, and assess if there are some trends in the change of the three parts of export growth. Secondly, while the method we use to calculate the three parts of export is based on Hummels and Klenow (2005), they only use their 
method to do a cross section analysis, but this paper uses it to make a comparative analysis between two time periods. The method used in this paper is also different from what is used in Shi (2011). In Shi (2011), there is no good way to separate out the effects of inflation, so price is not a good measurement of goods quality in his study. We construct the two indicators of China's export growth, quantity and price, relative to exports of the rest of the world. We not only break out the effects of inflation, but also assess China's performance relative to the rest of the world. Thirdly, different from other papers, here, unit price is an indicator which measures export quality, which, in turn, reflects both the export structure and the commodity quality. For a bundle of goods, unit price is mainly determined by quality of each commodity and the commodity structure of the goods. In other papers, unit price is only used to measure product quality.

\section{Literatures Review}

There have been many studies about the roles of the extensive and intensive margins in trade growth. Some conclude that the extensive margin plays a relatively more important role, while others find that the intensive margin plays the dominant role. Yi (2003) considers vertical specialization and trade in intermediates. He believes that a decline in the variable trade cost can lead to great increase in the trade of intermediates which is on the extensive margin; Hummels and Klenow (2005), using cross-sectional approach, examine cross-country differences in exports among a large sample of countries and find that the extensive margin accounts for 60 percent of the export increase of larger economies; Styliani (2010) finds significant evidence 
of growth in the extensive margin following a decrease in trade barriers between countries; Kehoe and Ruhl (2009) study the changes in bilateral trade between country pairs that undergo trade liberalization or significant structural transformation, and find that there is large increases on the extensive margin after trade liberalization or rapid economic growth; Foster et al. (2011) consider the trade creating effects of preferential trade agreements (PTAs) for a large sample of countries, and find that exports increase after the formation of PTAs, and that much of this increase occurs in the extensive margin.

On the contrary, Amiti and Freund (2010) analyze China's export growth patterns between 1992 and 2005, and find that the intensive margin plays a dominant role in the growth of China's exports; Helpman et al. (2008) decompose world trade growth after World War Two into extensive margin and intensive margin effects at the country level, and find that trade growth at the intensive margin is more important; Brenton and Newfarmer (2007) decompose exports for a wide range of developing countries into changes at the intensive and extensive margins, and take the view that most export growth for developing countries depends too much on the growth of existing products to existing markets; Besedes and Prusa (2011) decompose export growth into extensive margin and intensive margin, and confirm that the intensive margin is a crucial factor in the growth of trade. Similar research can be found in Felbermayr and Kohler (2006), Eaton et al. (2008).

There are several factors that lead to the differing results of the above papers. The first one is that different papers analyze exports at different levels and the 
definitions of extensive and intensive margin are accordingly different. For example, Brenton and Newfarmer (2007), Besedes and Prusa (2011), Hummels and Klenow (2005) use a definition at country-product level; Amiti and Freund (2010), Kehoe and Ruhl (2009) use a product level; Helpman et al. (2008), Felbermayr and Kohler (2006) use a country level; Eaton et al. (2008) is at firm level. Even papers that analyze exports at the same level may give different definitions of extensive and intensive margin. Exports classified as one margin may be classified as the other margin by another paper. These different levels of exports and the conceptual differences partly explain the different results regarding the relative importance of intensive margin and extensive margin.

The second one is that different papers analyze different countries, or the same country at a different time, or the same country at the same time but at different time length; Different countries and the same country at the different time may have different results regarding the relative roles of extensive and intensive margin; For the same country at the same time, if we consider different time length, we may get different results. For example, Bernard et al. (2009) decompose US trade growth into extensive and intensive margin effects and find that the variation in imports and exports across trading partners is primarily due to extensive margin, while variation in trade across one-year intervals is dominated by the intensive margin.

Only a few papers decompose the export growth into three parts: extensive margin, quantity and unit price. The expansion of the quantities of the same products is likely to cause a deterioration of the terms of trade. This bad effect can be offset in 
two ways: one is the growth of extensive margin; the other is improving quality. It is widely believed that export diversification is important. According to Pham and Martin (2007), part of the reason is that wide export diversification can lead to a stable economy; another part is that new products provide new opportunities for learning and productivity growth; another possible benefit of export diversification is that it can simulate demand because of the purchasers' preference for varieties. The other way to relieve the bad effect of expansion of the quantities is to raise the quality of the export goods and that increases the unit prices of export goods.

Hummels and Klenow (2005) decompose export growth into three parts and use data on shipments by 126 exporting countries to 59 importing countries in 5,000 product categories to study if big economies export larger quantities of each good, a wider set of goods (the extensive margin), or higher-quality goods. They find that the extensive margin accounts for around 60 percent of the greater exports of larger economies. Within categories, richer countries export higher quantities at modestly higher prices. So, they find that the extensive margin is important in explaining why big countries trade more than small countries, in that big countries trade more kinds of goods than smaller countries. Shi (2011) also decomposes data on China's export trade with 140 partners in 2001 and 2007 into the three parts and reaches the conclusion that China's export growth is mainly driven by quantity growth, which accounts for about $70 \%$ of overall export growth.

All of the above papers are similar in that they only focus on a specific period of time when they study the decomposition of export trade. These papers do not consider 
changes in the roles of the three parts stated above. There are a few papers that have referred to this issue. Imbs and Wacziarg (2003) find that countries tend to diversify production as they grow from low levels of income and that they only begin to specialize once they reach a relatively high level of income. Other papers reveals a strong positive correlation between the amounts of export varieties a country produces and its living standard (see Funke and Ruhwedel (2001)). This gives a hint that there may be a transformation of the roles of the three parts above with changing time, which means the role of the three parts may be different at different times.

Similar to Hummels and Klenow (2005) and Shi (2011), this paper decomposes the growth of export into three parts: extensive margin, quantity and price. This paper mainly aims to study the characteristics of China's export growth in these three parts. Firstly, we analyze the general characteristics of China’s export from 1995 to 2010; Then we divide the time period from 1995 to 2010 into five even phases, and study if there are some trends in the change of the three parts of export growth; The financial crisis in 2008 caused some special changes in the three parts, so, this paper studies china's export performance in the period following the crisis.

Recent studies have found that China is different from other developing countries in exporting highly sophisticated goods and China's export structure is similar to that of advanced countries. Rodrik (2006) and Schott (2008) find that the measured sophistication of China's exports far exceeds what would be expected from its stage of development. Another related issue is an ongoing debate in the literature about the quality content of Chinese exports. This paper also helps to assess how 
much export expansion depends on the quality content.

\subsection{Quantity}

In traditional theory, products are homogeneous, so there are neither horizontal nor vertical differences in products, and export growth can only be caused by the quantity growth alone. The Ricardian model suggests that countries export the goods in which they have relatively higher productivity. The standard Heckscher-Ohlin model suggests that relatively labor-abundant countries will export labour-intensive products whereas relatively capital-abundant countries will export capital-intensive products. In Armington models, each country produces a single variety in each category. For an individual country, more workers or higher productivity simply produces more of each variety, thus larger economies export greater value and volume with the varieties unchanged.

Melitz (2003), however, built a dynamic industry model with heterogeneous firms producing a horizontally differentiated good to analyze the intra-industry effects of international trade. His model suggests that exposure to trade induces only the most productive firms to enter the export market, the second most productive firms to serve only domestic market, and forces the least productive firms to exit. In equilibrium, a decline in variable trade costs causes a reallocation of production across firms leading to an aggregate productivity gain and an increase in welfare. Falling variable trade costs means greater profits for exporters, and higher export profits increase the value of exports by current exporters. A decrease in the fixed export cost will induce similar changes and a decrease in variable trade costs. So a decrease in the variable trade 
costs or the fixed export cost can increase the export quantity. In a different model, Bernard et al. (2003) construct a static Ricardian model of heterogeneous firms. In their model, firms use identical bundles of inputs to produce differentiated products under monopolistic competition. With positive trade costs, exporters are firms with productivity higher than the average level. As trade costs fall, aggregate productivity rises because high-productivity plants are more likely to expand at the expense of low-productivity firms which fail. A decrease in variable trade costs increases export sales by existing exporters and thus increases export quantity.

Helpman et al. (2004) introduce an additional choice for firms into Melitz's model, namely horizontal FDI. They then focus on firm choices between exports and horizontal FDI in supplying abroad. Firms with productivity above a certain point will not only supply domestic markets but also export to supply abroad. Firms with productivity above the other point will not only supply the domestic market, but also supply abroad via horizontal FDI. A decrease in variable trade costs and fixed trade costs of selling products abroad increases export sales by existing exporters, that is, increasing export quantity.

Gao and Whalley (2012) build on the Helpman et al. (2004) model to analyze different ways for multinational firms which have different productivity to serve the market abroad when production chains can be arbitrarily fragmented. Fragmentation is captured through the splitting of production chains across countries to yield a proximity advantage, but with a fixed cost of fragmentation production in foreign countries. Upon opening a market to trade, firms with the lowest productivity will exit, 
those with intermediate productivity will export, and those with higher productivity will choose fragmentation. Among the latter, the more productive a firm is, the more production chains are allocated abroad. Firms with the highest productivity will choose horizontal FDI. A decrease in transportation cost or in the fixed trade costs of selling products abroad or in the fixed cost for setting up a plant can increases export sales by existing exporters, and thus increases export quantity.

\subsection{Extensive margin}

Dornbusch et al. (1977) present a model with a continuum of goods where the range of goods produced domestically and imported is endogenously determined. A decrease of trade cost result in a shrinking range of non-traded goods, thus leading to more varieties of goods traded between nations and an increase in the extensive margin.

Krugman (1979, 1980) considers scale economies and consumers' taste for a diversity of products as an explanation for the intra-industry trade. In his model, countries produce commodities with an endogenous number of varieties. With fixed output costs of producing each variety, the number of varieties produced in a country is proportional to the size of the economy. Thus an economy that increases its size will produce and export more range of goods.

In more recent theories of heterogeneous firms, trade grows because of the acquisition of new exporting firms or new partners, which is also termed as the extensive margin. In Melitz (2003), when in equilibrium, a decrease in the variable and fixed trade cost will force the least productive firms to exit, but simultaneously 
generate the entry of new firms into the export market. Thus the extensive margin is increased. In Bernard et al. (2003) and Helpman et al. (2004), a decrease in variable trade costs increases the number of exporting firms; new exporters are drawn from the most productive non-exporters or new entrants. In Helpman et al. (2004), when there is a decrease in fixed trade costs of selling products abroad, new exporters are drawn from the most productive non-exporters or new entrants or the least productive firms who choose horizontal FDI. Thus more firms export than before.

In Gao and Whalley (2012), when transportation cost declines, the amount of firms that export are expanded in two directions, one is that some firms that only supply the home market before begin to export; the other is that some firms that formerly choose horizontal FDI will now choose fragmentation to supply abroad through exporting intermediates. So the export varieties (including intermediates) are expanded. With the development of technology and services, there will be more possibilities for fragmentation, so the proportion of firms that choose fragmentation will increase and more intermediates will be exported; the proportion of firms that choose exporting and horizontal FDI will decrease. Altogether, export varieties will increase.

Yi (2003) uses extensive margin to explain the growth in aggregate trade volumes. He considers fragmentation and takes the view that decline in the variable trade cost lead to great increase in the trade of intermediates. He argues that what used to be trade in final goods often becomes intermediates with international fragmentation deepening in the wake of tariff reductions, and in this process 
intermediates cross borders multiple times at different stages of production. This phenomenon suggests that even moderate tariff reductions can lead to pronounced trade expansion of intermediates in the extensive margin in the world wide.

\subsection{Price}

In Armington type models, countries can only expand their exports by driving down their prices relative to those supplied by other countries. So, in these models, the export quantity varies inversely with the price.

The prices of products are often used as proxies for quality, for example in Schott (2008), Xu (2010) and Shi (2011). In vertical intra-industry trade theory, as in Flam and Helpman (1987), products are differentiated by different qualities and different prices, so exports can also grow with upgrades in quality and subsequent price increases. In the literature on heterogeneous firms, one group focuses on quality sorting across firms, the other group on efficient sorting across firms. In the former group, more productive firms sell higher quality products at higher prices, while more productive firms sell commodities at lower prices in the latter group of studies. Quality sorting models thus provide an opposite prediction from the efficiency-sorting models.

\subsection{Other considerations}

According to the above literature, when a nation experiences a process of income rising or a trade liberalization, the extensive margin will be expanded and the quantity of trade will be raised. In most of the research, trade data with six or eight-digit HS categories are used, but it is still too aggregated to be able to identify new products. 
With the development of technology and more diversified preferences, more and more new varieties of commodities appear. But due to the restrictions of disaggregation, we can not capture all of the variety differences in the extensive margin. So generally speaking, the contribution of the extensive margin is usually underestimated, and that of the intensive margin is usually overestimated.

According to Hummels and Klenow (2005), even using the export data with more disaggregated categories, we still can not do well in assigning every variety difference to the extensive margin. If variety differences exist at more disaggregated levels (e.g., ten-digit), then we will capture only some of the variety differences in the extensive margin, and some will still be in the intensive margin. In this paper, we use six-digit HS trade data, and we should bear in mind the conclusion is based on these trade categories.

Many papers look at price as the indicator of commodity quality. Much information is embodied in the average price of a group of export commodities besides commodities' quality, such as export structure. Either export commodities' quality or export structure can lead to a change of the average price. For a nation as a whole, if the export structure has a change, the average price of the export will also change, even if the extensive margin and the commodities' quality be unchanged. For example, if a nation increases the proportion of high technology commodities in the total export, and decreases the proportion of low technology commodities, and if all other things remain constant, the average price of a nation's export will be increased. In this paper, we use the average price to measure export quality which embodies at 
least two sides, one is the commodities' quality, and the other is export structure. Higher commodities' quality leads to higher average price, but also the more improved the export structure is, the higher the average price is.

For the decomposition of the three parts of China's export growth, we consider both the supply and the demand side. On the supply side, we consider a nation with abundant labor supply and low level income at the beginning. When there is trade liberalization, there will be an increase in extensive margin and quantity. For the extensive margin, as it is said above, it will be expanded. The contribution of the extensive margin will probably be decreased gradually, for there is less and less room for the varieties to increase given the limited six or eight-digit HS categories. When the labor supply is abundant, because of the low cost of labor, the easy way to gain profit is to increase the quantity of existing varieties or begin to export existing varieties to new destinations facing trade liberalization. When the labor supply is in shortage, and the labor cost increases, the enterprises have the incentive to enhance the product quality to raise their competitiveness.

On the demand side, the demands of the consumers have three levels, one is quantity, and the other two are respectively varieties and quality. For an individual consumer, with an increase in his income, firstly his consumption focus is on the quantity to maintain a basic life, and then he may begin to consume varieties of commodities and like commodities with better quality. Combining supply side and demand side together, for a nation with abundant labor supply at the beginning experiencing trade liberalization, labor shortage and income increase, and the 
contribution of the extensive margin will probably be decreased gradually because of the restriction of disaggregated level of commodities; the contribution of the price will probably be increased gradually because of better and better commodities' quality and the improving export structure; The contribution of quantity will probably be increased at the beginning and then decreased because of trade liberalization and low wage labor at first and then a rising of labor cost. This is only a trend in a long time. In this paper, we only have the 1995-2010 trade data, and we want to assess China's trade reflects some of these characteristics during this time period. 


\section{Decomposition Method}

The method we use to decompose export growth into three parts is based on Hummels and Klenow (2005). Hummels and Klenow (2005) only use this method to do a cross section analysis, but this paper uses it to compare the three parts over time for China and makes a comparative analysis between two times, for example, we have a look at the change of the three parts between 2010 and 1995.

Adapting Feenstra’s (1994) methodology for incorporating new varieties into a country’s import price index, Hummels and Klenow (2005) construct the intensive margin, the category extensive margin, and the price and quantity components of the intensive margin. Let's consider China's export to $m$, with $k$ (the rest of the world) as the reference country. In this paper, China's shipments to $m$ are a subset of $k$ 's shipments to $m$, the extensive margin is defined as

$$
E M_{m}=\frac{\sum_{i \in I_{m}} p_{k m i} x_{k m i}}{\sum_{i \in I} p_{k m i} x_{k m i}}
$$

$I_{m}$ is the set of observable categories in which China has positive exports to $m$. In this paper, the $I$ categories will be 5,017 six-digit HS product codes of 1992 classification, and reference country $k$ has positive exports to $m$ in all $I$ categories. $E M_{m}$ equals country $k$ 's exports to $m$ in $I_{m}$ relative to country $k$ 's exports to $m$ in all $I$ categories. The extensive margin can be thought of as a weighted count of China's categories relative to $k$ 's categories with the weight of their importance in $k$ 's exports to $m$.

The corresponding intensive margin is given by 


$$
I M_{m}=\frac{\sum_{i \in I_{m}} p_{m i} x_{m i}}{\sum_{i \in I_{m}} p_{k m i} x_{k m i}}
$$

$I M_{m}$ equals China's nominal exports relative to k’s nominal exports in those categories China exports to $\mathrm{m}$. The ratio of China to country $\mathrm{k}$ exports to $\mathrm{m}$ equals the product of the two margins.

We now turn to decomposing the intensive margin into price and quantity indices. The price index for the intensive margin of country $m$ 's imports from China versus $k$ is:

$$
P_{m}=\prod_{i \in I_{m}}\left(\frac{p_{m i}}{p_{k m i}}\right)^{w_{m i}}
$$

In (3), $w_{m i}$ is the logarithmic mean of $s_{m i}$ (the share of category $i$ in China's exports to $m$ ) and $s_{k m i}$ (the share of category $i$ in $k$ 's exports to $m$, where $i \in I_{m}$ ). The price index can be thought of as a weighted count of China's export prices relative to k's export prices. The quantity index is:

$$
X_{m}=I M_{m} / P_{m}
$$

In reality, the quantity index can also be thought of as a weighted count of China's export quantities relative to $k$ 's export quantities.

Expressions (1) through (4) define our decomposition of China's exports to a given market $m$ (relative to $k$ 's exports to $m$ ).

Considering two time periods, period $t$ and period $t+1$, the ratio of China to the reference country $k$ exports to $m$ at time $t$ equals the product of the three parts:

$$
R_{t}=E M_{m t} P_{m t} X_{m t}
$$

The ratio of export between the two time periods can be expressed as

$$
R=\frac{R_{t+1}}{R_{t}}=\frac{E M_{m t+1}}{E M_{m t}} \frac{P_{m t+1}}{P_{m t}} \frac{X_{m t+1}}{X_{m t}}
$$


(6) can be expressed in the form of growth rates as

$$
g_{r}=g_{e x}+g_{p}+g_{q}
$$

So, we decompose the export growth rate $g_{r}$ into three parts: the extensive margin growth rate $g_{e x}$, price growth rate $g_{p}$ and quantity growth rate $g_{q}$. The contribution of each part is simply the growth rate of each part divided by the overall export growth rate, as shown in (8).

$$
r_{e X}=100\left(g_{e x} / g_{r}\right), \quad r_{p=100}\left(g_{p} / g_{r}\right), \quad r_{q=100}\left(g_{q} / g_{r}\right)
$$

We summarize the three parts across China's 35 biggest export destinations ${ }^{2}$ in 2010 as follows. These thirty five countries occupy more than $85 \%$ of China’s export in each year from 1995 to 2010. We first decompose China’s exports to each of these markets, and then we take the weighted average of China's decompositions across the 35 markets to get the sum total. The weight is the shares of China's export to $m$ in overall China exports.

In this paper, the data related with international trade are from BACI. BACI data are available for the Harmonized System (HS) with 6-digit disaggregation. The three main advantages of BACI data, in comparison with other similar databases, are its disaggregated product-level, broad geographical coverage and its unit values, which are more reliable than the raw data. More of the characteristics of BACI are described in Gaulier and Soledad (2010).

\footnotetext{
2 The name list of these 35 nations is in Table 1.
} 


\section{Decomposition Results}

We do three things. Firstly, we study the change in the three parts of China's export decomposition between 2010 and 1995; Secondly, we divide the time period from 1995 to 2010 into five even phases, and study the trend of the three parts' changes; Thirdly, we analyze China's export performance when facing the 2008 financial crisis.

\subsection{Changes between 2010 and 1995}

From 1995 to 2010, China's exports relative to the rest of the world experienced a remarkable growth. The last row in Table 1 tells us the change in these items at the level of 35 countries' sum total. The ratio of China's exports relative to the rest of the world to these 35 countries has been increased to 3.41. The average annual growth rate of $R, g_{r}$, is $8.19 \%$. The three parts of $g_{r}$, extensive margin growth rate $g_{e x}$, price growth rate $g_{p}$ and quantity growth rate $g_{q}$ are $1.17 \%, 1.55 \%$ and $5.47 \%$ respectively, with a contribution of $14.30 \%, 18.89 \%$ and $66.81 \%$ respectively. So, from 1995 to 2010, the intensive margin plays the relatively important role, it contributes to $85.70 \%$ of the growth of $R$. As a component of the intensive margin, the quantity margin plays the dominant role of $66.81 \%$. So, from 1995 to 2010, China's export growth is mainly driven by the quantity growth, secondly by the price growth, and thirdly by the extensive margin. 
Table 1 Changes in China’s export growth rates between 2010 and 1995

\begin{tabular}{|c|c|c|c|c|c|c|c|c|}
\hline China's trade with & $R$ & $g_{r}$ & $g_{e x}$ & $g_{p}$ & $g_{q}$ & $r_{e x}$ & $r_{p}$ & $r_{q}$ \\
\hline USA & 3.10 & 7.55 & 0.74 & 4.48 & 2.33 & 9.84 & 59.33 & 30.83 \\
\hline Hongkong & 1.44 & 2.44 & 0.24 & 0.94 & 1.25 & 10.03 & 38.71 & 51.26 \\
\hline Japan & 1.99 & 4.60 & 0.10 & 0.13 & 4.36 & 2.26 & 2.82 & 94.92 \\
\hline Korea & 2.98 & 7.28 & 0.59 & 1.42 & 5.27 & 8.07 & 19.46 & 72.47 \\
\hline Germany & 4.25 & 9.64 & 0.81 & 1.29 & 7.54 & 8.43 & 13.34 & 78.23 \\
\hline Netherlands & 6.23 & 12.19 & 1.54 & 2.36 & 8.29 & 12.64 & 19.36 & 68.00 \\
\hline India & 4.31 & 9.74 & 1.26 & -0.56 & 9.04 & 12.92 & -5.70 & 92.77 \\
\hline U.K. & 7.28 & 13.23 & 0.49 & 1.62 & 11.13 & 3.68 & 12.22 & 84.10 \\
\hline Singapore & 3.18 & 7.70 & 0.90 & 0.98 & 5.83 & 11.71 & 12.66 & 75.63 \\
\hline Italy & 3.94 & 9.15 & 0.44 & 0.86 & 7.84 & 4.85 & 9.43 & 85.72 \\
\hline Taiwan & 1.89 & 4.23 & -0.93 & 1.19 & 3.96 & -22.03 & 28.26 & 93.77 \\
\hline Russia & 3.33 & 8.01 & 2.17 & 0.64 & 5.20 & 27.06 & 7.98 & 64.96 \\
\hline France & 4.35 & 9.81 & 1.44 & 1.97 & 6.39 & 14.69 & 20.12 & 65.19 \\
\hline Australia & 3.30 & 7.97 & 2.06 & -0.36 & 6.26 & 25.84 & -4.46 & 78.62 \\
\hline Brazil & 16.11 & 18.53 & 3.11 & 0.14 & 15.27 & 16.80 & 0.77 & 82.43 \\
\hline Malaysia & 5.08 & 10.84 & 1.80 & 1.95 & 7.09 & 16.58 & 17.98 & 65.44 \\
\hline Vietnam & 3.03 & 7.40 & 0.96 & 2.13 & 4.31 & 12.95 & 28.85 & 58.20 \\
\hline Canada & 4.42 & 9.91 & 2.58 & -0.10 & 7.43 & 26.01 & -0.97 & 74.96 \\
\hline Indonesia & 4.10 & 9.40 & 1.00 & -1.01 & 9.41 & 10.66 & -10.73 & 100.07 \\
\hline United Arab Emirates & 2.95 & 7.21 & 1.81 & 1.30 & 4.10 & 25.08 & 18.01 & 56.91 \\
\hline Thailan & 4.53 & 10.07 & 1.44 & -1.17 & 9.80 & 14.27 & -11.64 & 97.37 \\
\hline Spain & 4.00 & 9.25 & 2.13 & 0.36 & 6.76 & 23.00 & 3.90 & 73.10 \\
\hline Mexico & 20.41 & 20.11 & 2.07 & 1.06 & 16.98 & 10.27 & 5.25 & 84.48 \\
\hline Belgium & 4.11 & 9.42 & 2.37 & -1.31 & 8.37 & 25.13 & -13.94 & 88.82 \\
\hline Panama & 5.21 & 11.01 & 8.12 & -1.77 & 4.65 & 73.79 & -16.06 & 42.27 \\
\hline Turkey & 5.79 & 11.71 & 4.63 & -1.27 & 8.35 & 39.56 & -10.88 & 71.32 \\
\hline Philippines & 2.05 & 4.78 & 3.02 & 0.13 & 1.63 & 63.31 & 2.62 & 34.07 \\
\hline Iran & 5.17 & 10.96 & 7.67 & 0.41 & 2.88 & 69.99 & 3.73 & 26.29 \\
\hline South Africa & 5.67 & 11.57 & 1.99 & -0.37 & 9.94 & 17.22 & -3.20 & 85.98 \\
\hline Saudi Arabia & 3.85 & 8.99 & 1.29 & -0.09 & 7.78 & 14.39 & -0.95 & 86.56 \\
\hline Polan & 5.03 & 10.78 & 5.66 & 1.09 & 4.03 & 52.49 & 10.13 & 37.38 \\
\hline Kazakstan & 5.25 & 11.05 & 3.25 & 0.00 & 7.80 & 29.42 & 0.00 & 70.58 \\
\hline Chile & 6.55 & 12.52 & 3.88 & 0.94 & 7.70 & 30.99 & 7.50 & 61.51 \\
\hline Czech & 14.27 & 17.72 & 5.09 & 1.17 & 11.45 & 28.74 & 6.62 & 64.64 \\
\hline Pakistan & 1.96 & 4.50 & 2.53 & 2.20 & -0.23 & 56.22 & 48.98 & -5.20 \\
\hline Total & 3.41 & 8.19 & 1.17 & 1.55 & 5.47 & 14.30 & 18.89 & 66.81 \\
\hline
\end{tabular}

Note: 1 . All entries except in $R$ column are in percentages; 2 . All the entries in $R, g_{r}, g_{e x}, g_{p}$ and $g_{q}$ columns are the values per year, and the entries in $r_{e x}, r_{p}$ and $r_{q}$ columns are the contributions of the three parts in the increase of exports from 1995 to 2010; 3. In calculating the sum total, the weight is the shares of China's export to $m$ in the overall China's exports in 2010. We also use the weight from data in 1995, the results are very similar. Source: Calculated by authors using data from BACI. 
The result that China's export growth was mainly driven by the quantity growth is similar to some other studies. In Shi (2011), China's export growth is mainly driven by quantity growth, which accounts for about $70 \%$ of overall export growth. In this paper, the average annually quantity growth rate is $5.47 \%$, which means that China's export quantity to the main destinations relative to the rest of the world has gained a large increase, and with a remarkable contribution of $66.81 \%$ 。

The extensive margin plays the least important role of the three parts. It only contributes to $14.30 \%$ of the growth of $R$. One of the important reasons is that six-digit HS categories are still too aggregated to identify new products, so the contribution of the extensive margin is a bit underestimated. Table 2 shows the extensive margins of the 35 countries in 1995 and 2010.

Table 2 China's bilateral extensive margins in 1995 and 2010

\begin{tabular}{|c|c|c|c|c|c|}
\hline & 1995 & 2010 & & 1995 & 2010 \\
\hline USA & 3518 & 4095 & Indonesia & 2820 & 4058 \\
\hline Hongkong & 4092 & 3987 & United Arab Emirates & 1576 & 3055 \\
\hline Japan & 3901 & 3994 & Thailand & 2854 & 3910 \\
\hline Korea & 3410 & 4056 & Spain & 2303 & 3507 \\
\hline Germany & 2973 & 3872 & Mexico & 1627 & 3397 \\
\hline Netherlands & 2308 & 3559 & Belgium & 2038 & 3419 \\
\hline India & 1836 & 3766 & Panama & 918 & 2792 \\
\hline U.K. & 2658 & 3825 & Turkey & 1561 & 3451 \\
\hline Singapore & 3208 & 3841 & Philippines & 1761 & 3704 \\
\hline Italy & 2601 & 3675 & Iran & 622 & 3347 \\
\hline Taiwan & 2405 & 3425 & South Africa & 2007 & 3688 \\
\hline Russia & 1543 & 3615 & Saudi Arabia & 2176 & 3092 \\
\hline France & 2626 & 3669 & Poland & 1055 & 3298 \\
\hline Australia & 2712 & 3745 & Kazakstan & 588 & 2332 \\
\hline Brazil & 1602 & 3424 & Chile & 1614 & 3186 \\
\hline Malaysia & 2918 & 3971 & Czech & 1220 & 2981 \\
\hline Vietnam & 1750 & 3396 & Pakistan & 1560 & 3364 \\
\hline Canada & 2489 & 3812 & Total & 76850 & 124308 \\
\hline
\end{tabular}

Source: Calculated by authors using data from BACI. 
The extensive margin in exports to big countries is larger than that for small countries. This is probably associated with the fixed cost in exporting that can be only covered in a big market. Figure 1 and Figure 2 describe the relationship between a country's GDP and China's export varieties to it in 1995 and 2010 respectively. In both of the two figures, the logarithm of 35 nations' GDP is represented on the horizontal axis, and the logarithm of 35 countries' export varieties is represented on the vertical axis. The two figures show the positive relationship between the extensive margin and the market scale. It is worth noting that most of the big countries in our sample liberalized much of their trade earlier than the small countries. This also explains why the extensive margin in export to big countries is larger than that in small countries.

Compared with 1995, nearly all the extensive margins in exporting to the 35 countries increase in 2010. Among these countries, the smaller the country is, the larger the increment is. Since small countries start from a low level extensive margin, when facing trade liberalization or some structural change, they will get a large increment in varieties when importing. In Figure 3, the logarithm of 35 countries' GDP in 2010 is represented on the horizontal axis, and the difference between logarithm of 35 countries' export varieties in 2010 and that in 1995 is represented on the vertical axis. This figure shows the negative relationship between the increment of extensive margin and the market scale. 
Figure 1 Relationship between a country’s GDP and China's export varieties to it in 1995

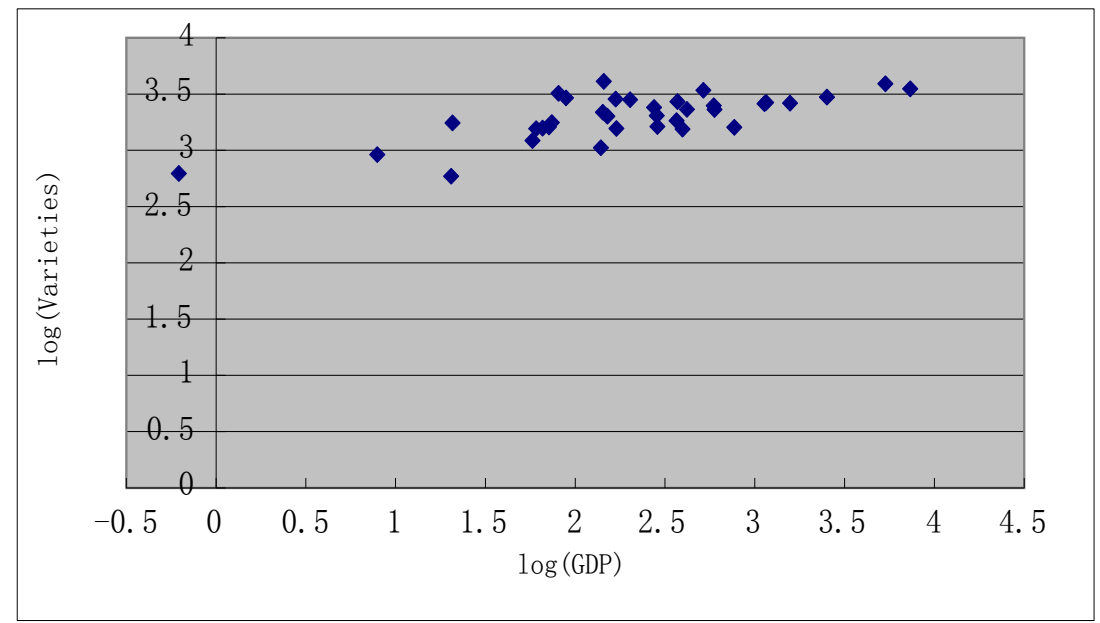

Figure 2 Relationship between a country’s GDP and China’s export varieties to it in 2010

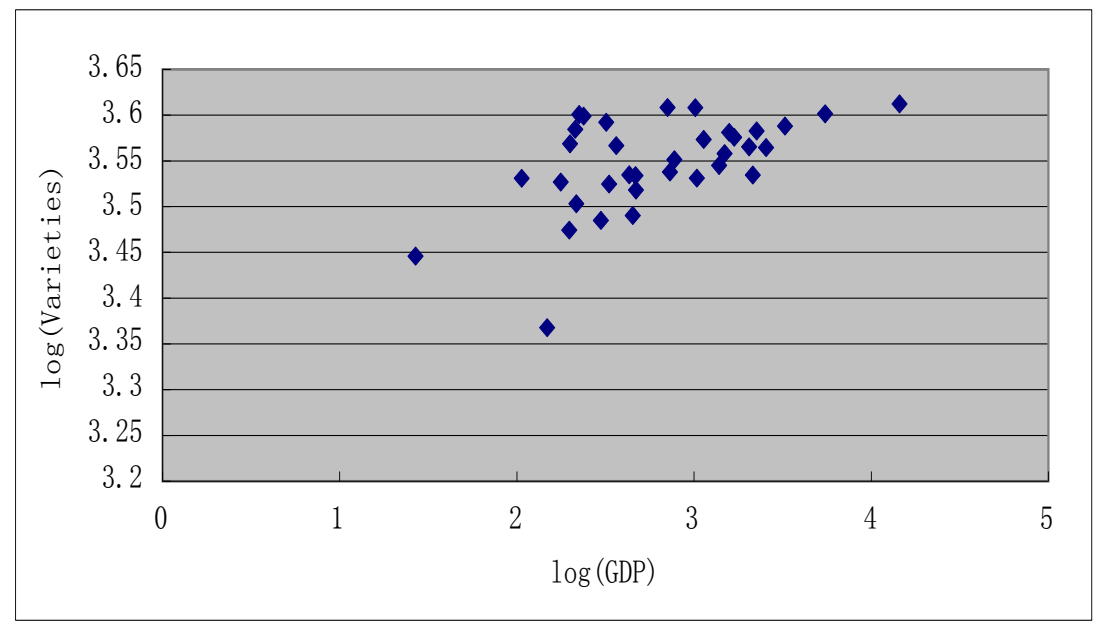

Figure 3 Relationship between the increment of extensive margin and the market scale

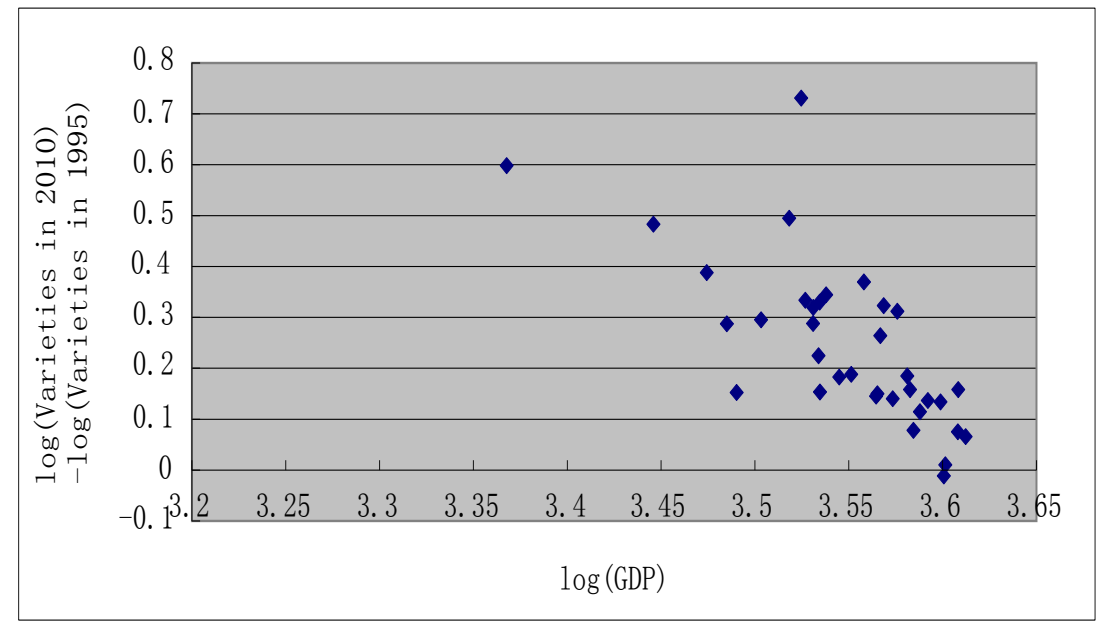

Source: In figure 1-3, GDP of Taiwan is from IMP World Economic Outlook Database; GDP of the other nations or regions are from World Bank databank; export varieties are calculated by authors using data from BACI. 
There is only a relatively small contribution of the price. It only contributes to $18.89 \%$ of the growth of $R$. From 1995 to 2010, the unit price growth rate is $1.55 \%$ per year. This shows China's export quality relative to the rest of the world is increasing a little annually.

The unit price reflects both the commodity quality and the export structure. Table 3 reports the great improvement of China's export structure. In 2010, China's export of medium technology manufactures (MTM) and high technology manufactures (HTM) rise sharply to 378,286 million and 550,692 million from a low level of 28,043 and 19,357 in 1995, and the share of these total exports rises to $24.1 \%$ and $35.1 \%$ from 1995's $19.0 \%$ and $13.1 \%$. For primary products (PP), resource based manufactures (RBM) and low technology manufactures (LTM), the share of them in total exports declines to $3.3 \%, 8.1 \%$ and $29.5 \%$ from 1995 's $10.0 \%, 11.2 \%$ and 46.7\% respectively. The improvment of the export structure can push the unit price higher even without the upgrading of the commodity quality. So in the studies that look at the unit price as the indicator of commodity quality, commodity quality is usually exaggerated if some of the contribution is due to the improvement of export structure.

Table 3 China’s export structure in 1995 and 2010

\begin{tabular}{cccccc}
\hline & PP & RBM & LTM & MTM & HTM \\
\hline 1995 & $148.07(10.0 \%)$ & $165.32(11.2 \%)$ & $689.38(46.7 \%)$ & $280.43(19.0 \%)$ & $193.57(13.1 \%)$ \\
2010 & $519.74(3.3 \%)$ & $1272.10(8.1 \%)$ & $4626.99(29.5 \%)$ & $3782.86(24.1 \%)$ & $5506.92(35.1 \%)$ \\
\hline
\end{tabular}

Note: 1. In Lall (2000), he gives a classification method to classify commodities into 5 categories based on the 3-digit SITC categories: primary products (PP), resource based manufactures (RBM), low technology manufactures (LTM), medium technology manufactures (MTM) and high technology manufactures (HTM); 2. The figures in every entries are the amounts of each category and in 100 million current price. 3 . The percentages in the brackets are the share of each category in the total export. 


\subsection{Different Sub Periods}

We divide the time period from 1995 to 2010 into five even sub periods. If we divide it into more phases, it's easier to reveal the trend of the change, but there is too short time in one period to grasp the change of the extensive margins. Bernard et al. (2009) find that variation in trade across one-year intervals is usually dominated by the intensive margin, and the relative contribution of the extensive margins rises across an interval of a few years.

In table 4 , for all these five sub periods, export growth rate $g_{r}$ gets a large increase which indicates that China's exports relative to the rest of the world increased greatly. The export growth rate can be decomposed into two parts: the extensive margin and the intensive margin. For the extensive margin $g_{e x}$, except 1995-1998 which are under the effect of financial crisis, it's a declining trend.

This result is consistent with Section 2. The reason is that the measure of the extensive margin is restricted by the HS six-digit category method, so the contribution of the extensive margin is to some extent underestimated. In the time of financial crisis, there is a small decrease in the extensive margin which can be seen in the 4.3. Except 1998-2001, $g_{p}$ is generally in a declining trend which shows the reducing speed of the improvement of export quality. This result doesn't accord with what we get in Section 2. This suggests that China's export quality relative to the rest of the world is still improving, not by an increasing speed but at a declining speed. The reason is complex, one of which is probably that China has felt the pressure of labor shortage, but it has not become a too serious problem. Furthermore, because of the 
relatively abundant labor supply, part of which is caused by the immigration of rural labor to the urban areas. $g_{q}$ is increasing and that shows China's export depends more and more on the quantity expansion. This result doesn't accord with what we get in Section 2. In this paper, quantity expansion is still the main way to increase export because of oversupplied labor. One of the reasons why $g_{p}$ is in a declining trend is that there is a negative relationship between quantity and price.

From the last three columns in Table 4, we also can see that the contributions of extensive margin and price are in a descending trend, but quantity in an increasing trend.

Table 4 Changes in growth rates in different sub periods

\begin{tabular}{ccccccccc}
\hline & $R$ & $g_{r}$ & $g_{e x}$ & $g_{p}$ & $g_{q}$ & $r_{e x}$ & $r_{p}$ & $r_{q}$ \\
\hline $1995-1998$ & 1.23 & 20.33 & -5.44 & 8.56 & 17.20 & -26.74 & 42.13 & 84.62 \\
$1998-2001$ & 1.30 & 25.95 & 4.53 & 6.36 & 15.06 & 17.45 & 24.51 & 58.03 \\
$2001-2004$ & 1.38 & 31.97 & 2.25 & 8.58 & 21.14 & 7.03 & 26.85 & 66.13 \\
$2004-2007$ & 1.24 & 21.26 & 1.11 & 3.53 & 16.63 & 5.21 & 16.59 & 78.20 \\
$2007-2010$ & 1.24 & 23.27 & -1.15 & 2.34 & 22.08 & -4.94 & 10.06 & 94.88 \\
\hline
\end{tabular}

Note: 1 . All the variables except $R$ are in percentage; 2 . All the entries are what happened during the corresponding time period, for example, the entries in the first line are what happened from 1995 to 1998.

Table 5 describes the changing speed of the five categories' share in total exports during the five periods. It shows that PP and RBM are declining at a reducing speed, and the other three categories firstly rise at an increasing speed then at reducing speed. In the period of 2007-2010, the changes of these five categories are little. This shows that the export structure is stabilizing. After 2004, the changes of MTM and HTM in the share of total export decline at a large scale, which explains part of the declining trend of $g_{p}$. 
Table 5 Change in export product structure in different sub periods

\begin{tabular}{lccccc}
\hline & PP & RBM & LTM & MTM & HTM \\
\hline $1995-1998$ & $-1.7 \%$ & $-2.1 \%$ & $-0.9 \%$ & $-0.4 \%$ & $5.2 \%$ \\
$1998-2001$ & $-1.3 \%$ & $-0.1 \%$ & $-5.8 \%$ & $1.4 \%$ & $5.9 \%$ \\
$2001-2004$ & $-2.2 \%$ & $-0.6 \%$ & $-6.7 \%$ & $2.2 \%$ & $7.3 \%$ \\
$2004-2007$ & $-1.2 \%$ & $-0.2 \%$ & $-2.1 \%$ & $1.2 \%$ & $2.3 \%$ \\
$2007-2010$ & $-0.3 \%$ & $0.0 \%$ & $-1.7 \%$ & $0.7 \%$ & $1.3 \%$ \\
\hline
\end{tabular}

Note: All the entries are the change of the items during the corresponding time period, for example, the entries in the first line are the change of proportion from 1995 to 1998.

\subsection{Export performance when facing the financial crisis}

In 2009, China’s export declined sharply compared with 2008. In 2008, China’s export amount is 1,431 billion dollars, but in 2009, the export amount dropped to 1,202 billion dollars ${ }^{3}$, and decreased by $16.0 \%$. While at the same period, the world export declined from 16,097 billion dollars to 12,461 billion dollars ${ }^{4}$, and decreased by $22.6 \%$. In 2010, China’s export resumed rapidly to 1,578 billion dollars ${ }^{5}$, with an increase of $31.3 \%$. While the world export in 2010 is 15,238 billion dollars ${ }^{6}$, with an increase of $22.3 \%$. So, when facing the financial crisis, China's export declined at a much smaller extent; a year later, China’s export came back with a much higher speed. Here we study what are the characteristics of the three margins of China's export during this financial crisis.

Table 6 Change in China's export growth rates when facing the 2008 financial crisis

\begin{tabular}{ccccccccc}
\hline & $R$ & $g_{r}$ & $g_{e x}$ & $g_{p}$ & $g_{q}$ & $r_{e x}$ & $r_{p}$ & $r_{q}$ \\
\hline $2008-2009$ & 1.11 & 10.14 & 0.01 & -5.76 & 15.90 & 0.05 & -56.78 & 156.73 \\
$2009-2010$ & 1.06 & 5.46 & -0.07 & 3.53 & 2.01 & -1.38 & 64.65 & 36.81 \\
\hline
\end{tabular}

Note: 1 . All the variables except $R$ are in percentage; 2 . All the entries are what happened during the corresponding time period, for example, the entries in the first line are what happened from 2008 to 2009.

From 2008 to 2009, China's export to the 35 nations relative to the rest of the

3 The data is from China Statistical Yearbook 2010.

4 The data is from International Statistical Yearbook 2011.

5 The data is from China Statistical Yearbook 2011.

6 The data is from International Statistical Yearbook 2011. 
world rose a bit since $R$ is 1.11 . This shows that China had a better performance than the rest of the world as a whole. The growth rate of the three parts of China's exports is as follows: intensive margin plays the dominant role, among the intensive margin, quantity relative to the rest of the world rises $15.90 \%$, while the price relative to the rest of the world decreases by 5.76\%; extensive margin changes little. Compared with 2008, we can see that China took a measure of lowering price and promoting sales in 2009 when facing the slump of export market. This policy leads China to a good performance in the world export market. The extensive margin remains nearly unchanged because one year's interval is not enough to grasp the change in the extensive margin. From Table 6, we can see that the contribution of the extensive margin to export is minor; the contribution of quantity is $156.73 \%$, and quality plays a negative role with a contribution of $-56.78 \%$. The main characteristic of China's first reaction to the financial crisis is one of lowering price and promoting sales.

From 2009 to 2010, China's export growth resumed rapidly with a much higher speed than the world. The growth rate of the three margins is as the following: quantity and price played a positive role in the export growth with an increasing rate of $2.01 \%$ and $3.53 \%$ respectively; the extensive margin played a slightly negative role with a decreasing rate of $0.07 \%$. So in 2010 , when facing an improving export conditions, China's export prices gained a growth rebound, and the quantity growths showed a steady increase. The negative extensive margin is one of the bad outcomes of the financial crisis. According to Jing (2012), the contraction of China's exports in 2009 occurs mainly on intensive margins, and it implies that China could come out of 
recession relatively easily once the macroeconomic conditions improve. China's export data in 2010 has confirmed this prediction to some extent. The main characteristic of China's reaction to the improving export conditions is that resuming price and increasing sales moderately.

Table 7 shows us the export structure from 2008 to 2010. In 2009, compared with 2008, only share of HTM increased. This shows that the export of HTM isn't greatly affected by the financial crisis. In 2010, the change of the export structure is very similar to that before 2008 .

Table 7 China's export product structure from 2008 to 2010

\begin{tabular}{cccccc}
\hline & PP & RBM & LTM & MTM & HTM \\
\hline 2008 & $491.66(3.5 \%)$ & $1238.02(8.7 \%)$ & $4368.17(30.7 \%)$ & $3528.11(24.8 \%)$ & $4617.68(32.4 \%)$ \\
2009 & $405.37(3.4 \%)$ & $952.18(8.0 \%)$ & $3618.45(30.3 \%)$ & $2827.51(23.7 \%)$ & $4151.64(34.7 \%)$ \\
2010 & $519.74(3.3 \%)$ & $1272.10(8.1 \%)$ & $4626.99(29.5 \%)$ & $3782.86(24.1 \%)$ & $5506.92(35.1 \%)$ \\
\hline
\end{tabular}

Note: 1 . The figures in every entries are the amounts of each category and in 100 million current price. 2. The percentages in the brackets are the share of each category in the total export. 


\section{Conclusion}

This paper decomposes the growth of China's export into three parts: extensive margin, quantity and price, and presents a series of empirical analyses using the China's export data in HS-6 digit to analyze the characteristics of China's export. This paper comes to the following conclusions:

From 1995 to 2010, China's export growth is mainly driven by the quantity growth. During this period, quantity, price and extensive margin has the contribution of $66.81 \%, 18.89 \%$ and $14.30 \%$ to export growth respectively. The extensive margin in export to big nations is larger than that in small nations. From 1995 to 2010, the growth rate of unit price is $1.55 \%$ per year, which shows China's export quality relative to the rest of the world is increasing a little yearly. The unit price is the indicator of export quality which mainly includes two sides: commodity quality and export structure. The large improvment of the export structure of China can push the unit price higher.

The three parts of the decomposition have a different changing trend. We divide the time period from 1995 to 2010 into five even phases. Generally speaking, the contributions of extensive margin and price are in a descending trend, but quantity is in an increasing trend. Quantity expansion is the main way to increase export, and its role becomes more and more important. Price index is in a descending trend, which shows that labor supply has not been a too much serious problem, and China is now still enjoying a population bonus.

China does better than the rest of the world in export growth when facing the 
2008 financial crisis. When facing the financial crisis, China's export growth declined at a much smaller extent; a year later, China's export came back with a much higher speed. The main characteristic of China's first reaction to the financial crisis is that lowering price and promoting sales greatly, and that of China's reaction to the improving export conditions is resuming price and increasing sales moderately.

These conclusions are based on the HS-6 digit trade data. In this paper, the extensive margin plays the least important role in the three parts. One of the important reasons is that six-digit HS categories are still too aggregated to identify all the new products, so the contribution of the extensive margin is a bit underestimated. If the available trade data can be further categorized, the role of the extensive margin will be somewhat larger, and that of the intensive margin will be a bit smaller. 


\section{References}

Amiti Mary, \& Freund Caroline (2010). An Anatomy of China's Export Growth. in Robert C. Feenstra and Shang-Jin Wei, (Eds.) China's Growing Role in World Trade, the University of Chicago Press, 35-56.

Bernard Andrew B., Eaton Jonathan J., Jensen Bradford, \& Kortum Samuel S. (2003). Plants and Productivity in International Trade. American Economic Review, 93 (4), 1268-1290.

Bernard Andrew B., Jensen Bradford J., Redding Stephen J., \& Schott Peter K. (2009). The Margins of US Trade. American Economic Review, 99 (2), 487-493.

Besedes Tibor, \& Prusa Thomas J. (2011). The Role of Extensive and Intensive Margins and Export Growth. Journal of Development Economics, 96 (2), 371-379.

Brenton P., \& Newfarmer R. (2007). Watching More than the Discovery Channel: Export Cycles and Diversification in Development, Paper presented to the Conference on Export Diversification, World Bank.

Dornbusch R., Fischer S. \& Samuelson P. A. (1977). Comparative Advantage, Trade, and Payments in a Ricardian Model with aContinuum of Goods. American Economic Review, 67 (5), 823-839.

Eaton Jonathan, Eslava Marcela, Kugler Maurice, \& James Tybout (2008). The Margins of Entry into Export Markets: Evidence from Colombia. in Elhanan Helpman, Dalia Marin, and Thiery Verdier, eds., The Organization of Firms in a Global Economy, Cambridge, MA: Harvard University Press, 231-272.

Feenstra Robert C. (1994). New Product Varieties and the Measurement of International Prices. American Economic Review, 84(1), 157-177.

Felbermayr Gabriel J., \& Kohler Wilhelm (2006). Exploring the Intensive and Extensive Margins of orld Trade. Review of World Economics, 142(4), 642-674.

Flam H., Helpman E. (1987). Vertical Product Differentiation and North-South Trade. American Economic Review, 77(5), 810-822.

Foster Neil, Poeschl Johannes, \& Stehrer Robert (2011). The impact of Preferential Trade Agreements on the margins of international trade. Economic Systems, 35(1), 84-97.

Funke M., \& R. Ruhwedel (2001). Product Variety and Economic Growth: Empirical Evidence for the OECD Countries, IMF Staff Papers, 48(2), 225-242.

Gao Yue, \& Whalley John (2012). Heterogeneous Firms in a Product Fragmentation World. ORF working paper, the University of Western Ontario, manuscript.

Gaulier Guillaume, \& Soledad Zignago (2010). BACI: International Trade Database at the Product-Level. The 1994-2007 Version. Working Papers 2010-23, CEPII research center.

Helpman E., M. Melitz \& Y. Rubinstein (2008). Estimating Trade Flows: Trading Partners and Trading Volumes. Quarterly Journal of Economics, 123(2), 441-487.

Helpman E., M. Melitz \& S. Yeaple, "Export versus FDI with Heterogeneous Firms”, American Economic Review, 2004, 94(1), 300-316.

Hummels David, \& Klenow Peter L. (2005). The Variety and Quality of a Nation's Exports. The American Economic Review, 95(3), 704-723.

Imbs Jean \& Romain Wacziarg (2003). Stages of Diversification. American Economic Review, 93(1), 63-86. 
Jing Ran (2012). The Collapse Speed of China's Exports in the 2008-2009 Financial Crisis. CESifo Economic Studies, 58(4), 650-670.

Kehoe Timothy J., \& Ruhl Kim J. (2009). How Important Is the New Goods Margin in International Trade? Federal Reserve Bank of Minneapolis Research Department Staff Report 324.

Krugman Paul R. (1980). Scale Economies, Product Differentiation, and the Pattern of Trade. American Economic Review, 70(5), 950-959.

Krugman Paul R. (1979). Increasing returns, monopolistic competition, and international trade. Journal of International Economics, 9(4), 469-479.

Lall Sanjaya (2000). The Technological Structure and Performance of Developing Country Manufactured Exports, 1985-98. Oxford Development Studies, 28(3), 337-369.

Melitz M. (2003). The Impact of Trade on Intra-industry Reallocations and Aggregate Industry Productivity. Econometrica, 71(6), 1695-1725.

Pham, C., \& Martin W. (2007). Extensive and Intensive Margin Growth and Developing Country Exports. Mimeo, World Bank, Washington, DC.

Rodrik Dani (2006). What is so special about China's exports? China \& World Economy, 14(5), $1-19$.

Schott Peter K. (2008). The relative sophistication of Chinese exports. Economic Policy, 53, 5-49. Shi Bingzhan (2011). Extensive Margin Quantity and Price in China's Export Growth, China Economic Review. 22(2), 233-243.

Styliani Christodoulopoulou (2010). THE Effects of Multilateral Trade Liberalization on the Extensive and the Intensive Margins of Trade, manuscript.

Xu Bin (2010). The sophistication of exports: Is China special? China Economic Review, 21(3), 482-493.

Yi Kei-Mu (2003). Can Vertical Specialization Explain the Growth of World Trade. Journal of Political Economy, 111(1), 52-102. 